\title{
Bacteriological Evaluation of Locally Marketed Ice Cream in Navsari City of Gujarat
}

\author{
Deepti N. Nayak ${ }^{1 *}$, J. B. Solanki ${ }^{2}$, C. V. Savalia ${ }^{1}$ and Pushpa Makwana ${ }^{3}$ \\ ${ }^{1}$ Department of Veterinary Public Health and Epidemiology, ${ }^{2}$ Department of Veterinary \\ Parasitology, ${ }^{3}$ Department of Veterinary Microbiology, College of Veterinary Science \& \\ Animal Husbandry, Navsari, India \\ *Corresponding author
}

\section{A B S T R A C T}

\begin{tabular}{|l|}
\hline Key w or d s \\
Ice cream, \\
$\begin{array}{l}\text { Staphylococcus } \\
\text { aureus, } \text { E. coli }\end{array}$ \\
\hline Article Info \\
\hline $\begin{array}{l}\text { Accepted: } \\
16 \text { November } 2020 \\
\text { Available Online: } \\
10 \text { December } 2020\end{array}$ \\
\hline
\end{tabular}

\section{Introduction}

Ice cream is a popular frozen dessert consumed by people of all age groups. In addition to milk, it contains a variety of ingredients like fresh and dry fruits, jelly, colours and flavours (Naim et al., 2014). The ingredients may serve as source of various microorganisms and will eventually affect the quality of ice cream.

The high percentage of lactose and proteins in ice cream, as well as the neutral $\mathrm{pH}$, make it a good growth medium for many microorganisms that eventually cause diseases in the consumers, such as cholera, typhoid and chronic intestinal diarrhea (Jabuk et al., 2019). Growth and multiplication of various bacteria may take place during production, packaging, storage and distribution of the product. Psychrotrophic bacteria like Listeria monocytogens, Staphylococcus aureus, Bacillus spp., Salmonella spp., Shigella, Streptococcus spp., Psedudomonas spp. have been recovered from dairy food products (Das et al., 2020). This study was conducted to assess the microbiological quality of locally produced ice cream sold in Navsari city 


\section{Materials and Methods}

A total 150 samples (as mentioned in Table 1) were collected in sterile collection tubes from different locations of Navsari city and analyzed at the department of Veterinary Public Health and Epidemiology, College of Veterinary Science \& Animal Husbandry, Navsari.

\section{Isolation of Salmonella spp.}

For isolation of Salmonella spp., preenrichment of $25 \mathrm{~g}$ sample was done in $225 \mathrm{ml}$ of $10 \%$ buffered peptone water at $37^{\circ} \mathrm{C}$ for 24 hours followed by selective enrichment of 0.1 $\mathrm{ml}$ pre-enriched sample in $10 \mathrm{ml}$ RappaportVassiliad is Soy Broth at $37^{\circ} \mathrm{C}$ for 24 hours and finally plating of inoculum from enrichment media on Xylose Lysine Deoxycholate (XLD) agar incubated at $37^{\circ} \mathrm{C}$ for 24 hours.

\section{Isolation of E. coli and Staphylococcus aureus}

For Isolation of E. Coli and Staphylococcus aureus enrichment of $25 \mathrm{~g}$ sample was done in $225 \mathrm{ml}$ of $1 \%$ buffered peptone water at $37^{\circ} \mathrm{C}$ for 24 hours followed by plating on Eosin Methylene Blue (EMB) agar for E. Coli and on Baird Parker agar (BPA) for Staphylococcus aureus, respectively, and incubation of the plates at $37^{\circ} \mathrm{C}$ for $24-48$ hours.

For identification of the isolates, Gram's staining and biochemical tests like Indole, MR VP, Nitrate, Citrate, Catalase, Urease, TSI were conducted using standard laboratory methods.

\section{Results and Discussion}

Out of 150 samples examined during the study, Salmonella spp. was not detected in any of the samples. Similar findings were recorded by Maifreni et al., 1993; Kivanc et al., 1994; Warke et al., 2000 and Kanbakan et al., 2004.

Staphylococcus aureus was detected in 69 (46\%) samples collected from various locations as mentioned in Table 1. Higher contamination rates of $62.3 \%$ and $100 \%$, at the counts above the safe limit level were also reported by Kivanc et al., (1994) and Warkeet al., (2000). In the city of Kolhapur, Jadavet al., (2004) observed that $40 \%$ ice cream samples were positive for Staphylococcus spp. most of them were purchased from road vendors. A total 22 (22\%) Staphylococcus aureus isolates were detected from 100 samples of ice cream by Samir et al., (2018) in Egypt and nearly similar isolation rates for Staphylococcus aureus were observed in the studies conducted by Kamal et al., (2009) at 22.9\%, Moshood et al., (2013) at 20\% and Tawab et al., (2016) at 26\%. The presence of Staph.aureus may be due to glitch in the process of pasteurization or human exposure. In humans, Staph.aureus inhabits the skinarms, hands, and face being the main sources, nasal cavity, eyes, throat and intestinal tract. From these sources, the organism finds its way into air, dust and fomites from which it may contaminate foods Normanno et al., (2007). Contamination also indicates inadequate personal hygiene of workers during manufacturing and vendors selling the ice cream.

Escherichia coli was detected in $17(11.33 \%)$ samples, as shown in Table 1. E. coli was detected in 15 out of $73(20.55 \%)$ ice cream samples (Yaman et al., 2006). In studies conducted on ice cream samples in Turkey, incidence rates of $22 \%$ and $3.33 \%$ were reported by Kivanc et al., (1994) and Erol et al., (1998) in different cities. Masud (1989) reported E. coli in 23 out of 50 samples (46 $\%)$ analyzed. Anenteric pathogen, E. coli, in 
samples indicates faecal contamination of water used during preparation of the product or for cleaning of the equipments and utensils.
Also it is an indicator of workers not following basic self-hygiene practices during production.

Table.1 Samples collected from different areas of Navsari city

\begin{tabular}{|c|c|c|c|}
\hline Area of collection & $\begin{array}{c}\text { Number of } \\
\text { samples }\end{array}$ & $\begin{array}{l}\text { Samples positive } \\
\text { for } E \text {. coli }\end{array}$ & $\begin{array}{l}\text { Samples positive for } \\
\text { Staphylococcus aureus }\end{array}$ \\
\hline Navsari railway station & 10 & 10 & 10 \\
\hline Gopal Nagar & 12 & ------ & 12 \\
\hline Eru char rasta & 8 & 6 & 8 \\
\hline Sandkuwa & 4 & ------ & ------ \\
\hline Fuwara & 12 & ------ & ------ \\
\hline ShivajiChowk & 12 & ------ & ------ \\
\hline Tower & 8 & ------ & ------ \\
\hline Market & 12 & ------ & ------ \\
\hline Jamalpore & 4 & ------ & ------ \\
\hline Bus Depot + Nearby area & 12 & ------ & 12 \\
\hline Circuit House & 4 & ------ & ------ \\
\hline Station Road & 4 & 1 & 4 \\
\hline Jalalpore & 8 & ------ & 8 \\
\hline Lunsikui & 12 & ------ & 8 \\
\hline Grid road & 12 & ------ & 5 \\
\hline Veravalnaka & 8 & ------ & 1 \\
\hline Zaveri Road & 8 & ------ & 1 \\
\hline TOTAL & 150 & $17(11.33 \%)$ & $69(46 \%)$ \\
\hline
\end{tabular}

In conclusion the ice- cream is a favorite food to many but if not correctly manufactured, stored and handled it can become a source of infection. Ice creams manufactured in domestic premises is more prone to contamination and thus may act as vehicle for gastrointestinal diseases. From the current findings it could be opined that $E$. coli and Staph. Aureus may become a cause of food borne illness due to consumption of such ice cream. The quality of raw milk used, raw materials like sugar, nuts or fruit added to the ice cream, maintaining cod-chain during storage and transportation of the final product, and handling of the product by vendors at the point of sale as well as personal hygiene are critical steps in preventing the growth of undesirable microorganisms. It is observed that habits like washing of hands before handling the product, frequent cleaning of scoops used for dispensing the ice-cream, maintaining cleanliness of surfaces in the shop are not very strictly practiced by the vendors. Also, in shops where a constant inflow of customers is expected and those located in busy and crowded areas are more likely to be contaminated due to frequent opening and handling of the containers. Therefore, it is essential for local vendors to adopt good manufacturing practices as well as hygienic distribution and storage practices for ensuring microbiological safety of ice cream sold to customers. 


\section{Acknowledgement}

The authors are grateful to acknowledge the support rendered by the Dean, Veterinary College and Director of Research \& Dean, PGS, Navsari Agricultural University, Navsari, Gujarat, India by providing necessary facilities and resources to write this research article.

\section{References}

Das, M., Mishra, A., Dutta, P. P. and Basena, K. N. (2020). Bacteriological evaluation of few industrially produced ice creams marketed in Jorhat, Assam, India. International. Journal of Chemical Studies, 8(2): 2946-2950.

Erol, I., Kuplulu, O., Siriken, B. and Celik, T. H. (1998). Determination of Microbiological Quality of Ice-Cream Belong to Various Patisserie in Ankara. Turkish Journal of Veterinary and Animal Sci., 22: 345-352.

JabukSura I. A., Al-Sultany Dhurgham, A. A., Hashim, Kadhim Kh. (2019). Bacterial Contamination of the Local Available Ice Cream in Hila City. Indian Journal of Public Health Research \& Development, 10(10).

Jadhav, A. S. and Raut, P. D.(20140. Evaluation of microbiological quality of ice creams marketed in Kolhapur city, Maharashtra, India. International Journal of Current Microbiology and Applied Sciences, 3(9): 78-84.

Kamal R. M. (2009). Sanitary status of some locally and imported dairy products. Ph.D. Thesis, Zag University, Egypt.

Kanbakan, U., Con, A. H. and Ayar, A.(2004). Determination of microbiological contamination sources during ice cream production in Denizli, Turkey. Food Control, 15: 463-470.

Kivanc, M., Yamac, M. and Kunduhoglu, B.(1994).Microbiological Analysis of
Ice Cream offered to Public Consumption in Eskișehir. Gida.19(5): 317-322.

Maifreni, M., Civilini, C, Domenis, M., Manzano R. Di Prima, and Comi, G. (1993). Microbiological quality of artisanal ice cream. Zentralbl. Hyg. Umwetmed., 194: 553570.

Masud, T. (1989). Microbiological quality and public health significance of ice cream. Journal of Pakistan Medical Association, 39(4): 102-104.

Moshood, A. Y., Tengku, H. A., Tengku, A. H., Moshood A. (2013). Assessment Of The Bacteriological Quality Of Ice Cream Offered For Public Consumption In Bauchi, Nigeria. IOSR Journal of Pharmacy, 3: 25-30.

Naim, A., Khan, M. Z. A., Anand, A. and Kumari, S. (2014). Microbiological Analysis of Mixed \& Plain Ice Cream Samples Sold in Local Markets of Allahabad. International Journal of Pure and Applied Biosciences, 2(3): 246-254.

Normanno, G., La Salandra, G., Dambrosio, A., Quaglia, N. C., Corrente, M., Parisi, A., Santagada, G., Firinu, A., Crisetti, E. and Celano, G. V. (2007). Occurrence, characterization and antimicrobial resistance of enterotoxigenic Staphylococcus aureus isolated from meat and dairy products. International Journal of Food Microbiology.,115: 290-296.

Samir H, Younis W, Sultan S and Abd ElAzeem MW.(2018).Isolation of Staphylococcus aureus from Ice-Cream Samples. Journal of Veterinary and Animal Research 1(2): 1-5

Tawab, A. A. Abd. El, Ammar, M. A., ElHofy I. F. and Aideia, A. H.(2016). Bacteriological and molecular studies on toxigenic Staphylococcus aureus in milk and some milk products. Benha Veterinary Medical Journal, 31: 202- 
209.

Warke, R., Kamat, A., Kamat, M., Thomas, P. (2000). Incidence of pathogenic psychrotrophs in ice creams sold in some retail outlets in Mumbai, India. Food Control, 11: 77-83.
Yaman H, Elmali M, Ulukanli Z, Tuzcu M and Genctav K. (2006). Microbial quality of ice cream sold openly by retail outlets in Turkey. Review of Med. Vet.157 (10): 457-462.

\section{How to cite this article:}

Deepti N. Nayak, J. B. Solanki, C. V. Savalia and Pushpa Makwana. 2020. Bacteriological Evaluation of Locally Marketed Ice Cream in Navsari City of Gujarat. Int.J.Curr.Microbiol.App.Sci. 9(12): 2236-2240. doi: https://doi.org/10.20546/ijcmas.2020.912.263 